\title{
POLA AKTIVITAS, KONSUMSI PANGAN, STATUS GIZI DAN KESEHATAN ANAK J ALANAN DI KOTA BANDUNG
}

\author{
(Activity Pattern, Food Consumption, Nutritional and Health Status of Street Children \\ in Bandung)
}

Nur'aini ${ }^{1}$ dan Mira Dewi ${ }^{2^{*}}$

1 Program Studi Gizi Masyarakat, Fakultas Ekologi Manusia, Institut Pertanian Bogor, Bogor 16680
2* Departemen Gizi Masyarakat, Fakultas Ekologi Manusia, Institut Pertanian Bogor, Bogor 16680
Tel: 0251-8621258; Fax: 8622276; Email: miradewi2006@yahoo.co.id

\begin{abstract}
ABST RACT
The objective of the research was to analyze activity pattern, dietary consumption, nutritional status and health of street children in Bandung. Cross sectional design was used in this study to elaborate activity pattern, food consumption, nutritional status and health of street children in Bandung. Samples of street children was recruited by purposive sampling from eight NGOs in Bandung with following criterias: 1) 5-18 years old 2) spend time on the street at least four hours a day 3) work for living on the street, commonly as singers, beggars, shoe-polisher, porters etc. The result showed that most of the street children worked as singers, spend 4-8 hours a day and 4-6 days a week. The average energy and protein adequacy level of street children was in light deficit category, iron and vitamin C were in low category and vitamin A was in sufficient category. Almost all of the street children had normal nutritional and health status and good personal hygiene. There was no correlation between activity and duration of street children with nutrition adequacy level. There was no correlation between personal hygiene and nutritional status with health status.
\end{abstract}

Keywords: street children, nutritional status, health status, pattern activity, food consumption

\section{PENDAHULUAN}

Deklarasi Universal PBB tentang Hak Asasi Manusia tahun 1948 menyatakan bahwa setiap orang berhak untuk memperoleh kesehatan yang baik dan pangan yang cukup sehingga terbebas dari kelaparan dan kurang gizi (Soekirman, 2000). Sesuai deklarasi tersebut, salah satu kelompok yang perlu diperhatikan dan berhak untuk memperoleh kesehatan yang baik dan pangan yang cukup adalah anak jalanan.

Semenjak krisis ekonomi yang melanda Indonesia, jumlah anak jalanan di kota besar terus meningkat dari tahun ke tahun. Pemetaan sosial terhadap 12 kota besar di Indonesia yang dilakukan PKPM Universitas Atmajaya pada tahun 1999 (Irwanto et al., 1999) menunjukkan bahwa jumlah anak jalanan di berbagai kota besar amatlah tinggi. Pemetaan menunjukkan ada sekitar 39861 anak jalanan di berbagai kota besar: sekitar 10373 berada di Jakarta, 2832 di Bandung dan 2835 di Surabaya (Moeliono, 2001).

Anak jalanan identik dengan kemiskinan dan kurangnya akses terhadap makanan yang bergizi. Salah satu masalah kesehatan yang dapat terjadi adalah keadaan kurang gizi karena pola makan yang tidak teratur. Selain kurangnya akses terhadap makanan bergizi terkait kemiskinan, keadaan kurang gizi merupakan salah satu faktor penyebab mudahnya seseorang terkena penyakit infeksi, hal ini karena sistem kekebalan tubuh alami yang dimiliki melemah. Selain itu status kesehatan anak jalanan yang buruk juga dapat menyebabkan status gizi menjadi buruk (Indriani, Adiningsih \& Mahmudiono, 2006).

Tujuan dari penelitian ini ialah untuk menganalisis pola aktivitas, konsumsi pangan, status gizi dan kesehatan anak jalanan di Kota Bandung.

\section{METODE PENELITIAN}

\section{Desain, Tempat, dan Waktu Penelitian}

Penelitian ini menggunakan desain cross sectional study dan merupakan bagian dari penelitian Aspek Sosio-ekonomi dan Faktor Lingkungan yang Mempengaruhi Status Gizi dan Kesehatan Anak Jalanan. Penelitian dilakukan di 
Kota Bandung yang merupakan Ibu Kota Provinsi Jawa Barat dan salah satu kota besar di Indonesia. Pemilihan lokasi tersebut didasarkan pada alasan bahwa anak jalanan di Indonesia umumnya tinggal di kota besar. Waktu pengambilan data dilakukan pada bulan Februari 2009.

\section{J umlah dan Cara Penarikan Contoh}

Populasi pada penelitian payung ini adalah kelompok anak jalanan yang melakukan aktivitas di jalan dan berusia antara 5-18 tahun. Pengambilan contoh dilakukan secara purposive sebanyak 300 anak jalanan di delapan rumah singgah yang tersebar di Kota Bandung. Pemilihan rumah singgah dilakukan dengan pertimbangan kemudahan akses.

Penelitian ini dilakukan di dua rumah singgah di Kota Bandung secara purposive. Jumlah contoh yang terdapat di kedua rumah singgah sebanyak 51 orang dengan kriteria (1) berusia 5-18 tahun, (2) melakukan aktivitas di jalan minimal 4 jam dalam sehari serta (3) memperoleh pendapatan dari bekerja di jalanan seperti mengamen, mengemis, menyemir sepatu, berjualan dan jasa lainnya. Pengambilan data orangtua/wali contoh diperoleh secara purposive yang berjumlah 28 orang.

\section{Pengolahan dan Analisis Data}

Data yang digunakan ialah data sekunder. Data sosial-ekonomi seperti pendidikan, pendapatan dan kebiasaan makan (preferensi pangan dan konsumsi) diperoleh melalui wawancara sedangkan data penyakit infeksi dan status kesehatan dikumpulkan melalui wawancara dan pemeriksaan fisik langsung. Data antropometri digunakan untuk menghitung indeks masa tubuh (IMT) sebagai indikator status gizi.

Tingkat kecukupan energi dan protein dibedakan menjadi empat cut off points menurut Departemen Kesehatan (1996) yaitu: (1) defisit tingkat berat (<70\% AKG); (2) defisit tingkat sedang (70-79\% AKG); (3) defisit tingkat ringan (80-89\% AKG); (4) normal $(90-119 \%$ $A K G)$; dan (5) kelebihan ( $\geq 120 \%$ AKG). Klasifikasi tingkat kecukupan zat besi, vitamin $A$, dan vitamin C menurut Gibson (2005) yaitu (1) kurang (<77\% AKG) dan (2) cukup ( $\geq 77 \%$ AKG).

Frekuensi konsumsi jenis pangan diukur berdasarkan frekuensi konsumsi jenis pangan tertentu dalam satu bulan terakhir dan cara memperoleh pangan dikelompokkan menjadi enam yaitu (1) dibeli, (2) ditanam/dipelihara sendiri, (3) diberi, (4) barter, (5) dari alam (memancing, berburu), dan (6) memulung.
Pengukuran status gizi anak jalanan dilakukan dengan metode antropometri melalui perhitungan Indeks Massa Tubuh menurut umur (IMT/U). IMT/U digunakan untuk anak yang berumur 5-19 tahun. Untuk menilai kurus nilai $\mathrm{Z}$ score adalah $\mathrm{Z} \leq 2$, normal berada pada kisaran $-2<z<2$ dan gemuk $z \geq 2$ (WHO, 2007). Referensi yang digunakan adalah tabel WHO 2007 yaitu IMT menurut umur (Z-score). Status kesehatan pada penelitian ini dibatasi oleh penyakit diare, infeksi pernapasan akut dan penyakit kulit.

Higiene personal diukur dengan 13 pernyataan mengenai pemeliharaan kebersihan tubuh dan pakaian dalam kehidupan seharihari seperti kebiasaan mandi, keramas, gosok gigi, cuci tangan dan mengganti baju seusai mandi. Penilaian higiene personal dilakukan dengan memberi skor pada setiap pertanyaan. Bila menjawab tidak pernah diberi skor 0 , bila menjawab jarang diberi skor 1 dan bila menjawab selalu diberi skor 2 . Total skor yang diperoleh diklasifikasikan menjadi tiga berdasarkan rumus interval yaitu rendah (11-16), sedang (17-21) dan tinggi (22-26). Pengkategorian ini berdasarkan interval kelas yang rumus perhitungannya adalah sebagai berikut :

Interval kelas $=\underline{\text { nilai tertinggi }- \text { nilai terendah }}$ Jumlah kelas

Analisis dilakukan dengan menggunakan statistik deskriptif dan inferensia. Hubungan antar variabel yang berupa data kategorik diuji menggunakan korelasi Spearman sedangkan untuk data berjenis rasio digunakan uji korelasi Pearson. Analisis data diolah dengan menggunakan Microsoft Excel 2007 dan Statistical Program for Social Sciences (SPSS) version 16.0 for windows.

\section{HASIL DAN PEMBAHASAN}

\section{Latar Belakang Menjadi Anak J alanan}

Beberapa alasan contoh turun ke jalan adalah faktor ekonomi (64.7\%), diajak teman (19.6\%) dan lainnya (15.7\%). Alasan lainnya dalam hal ini adalah faktor keluarga dan untuk sekedar mengisi waktu. Hal ini menunjukkan bahwa alasan utama contoh turun ke jalan adalah ekonomi (64.9\%).

Sebagian besar orangtua contoh bekerja di sektor informal bahkan ada pula orangtua contoh yang menganggur. Pekerjaan ayah terbanyak adalah buruh (30.4\%) sedangkan sebagian besar ibu bekerja sebagai pembantu ru- 
mah tangga (17.2\%). Sebagian besar contoh turun ke jalan karena alasan ekonomi tetapi berdasarkan garis kemiskinan di Kota Bandung, lebih dari separuh (64.3\%) keluarga contoh tergolong keluarga tidak miskin (pendapatan/kapita/bulan > Rp203 751). Hal ini disebabkan hampir setiap anggota keluarga bekerja mencari uang sehingga pemasukan dari anggota keluarga cukup besar.

\section{Karakteristik Contoh}

Sebagian besar (47.1\%) orang tua mendukung contoh untuk turun ke jalan mencari uang dan sebagian besar contoh (90.2\%) masih tinggal dengan orangtua. Hal ini menunjukkan bahwa sebagian besar contoh termasuk dalam kategori children on the street. Contoh turun ke jalan hanya untuk bekerja dan masih pulang ke rumah serta tinggal dengan orang tua.

Di Indonesia, yang disebut pekerja anak di jalan adalah anak yang menghabiskan sebagian besar waktunya untuk bekerja di jalan atau tempat-tempat umum untuk membantu keluarganya. Pada umumnya mereka bekerja untuk memperoleh pendapatan (Moeliono, 2001).

Tabel 1. Sebaran Contoh menurut Karakteristik

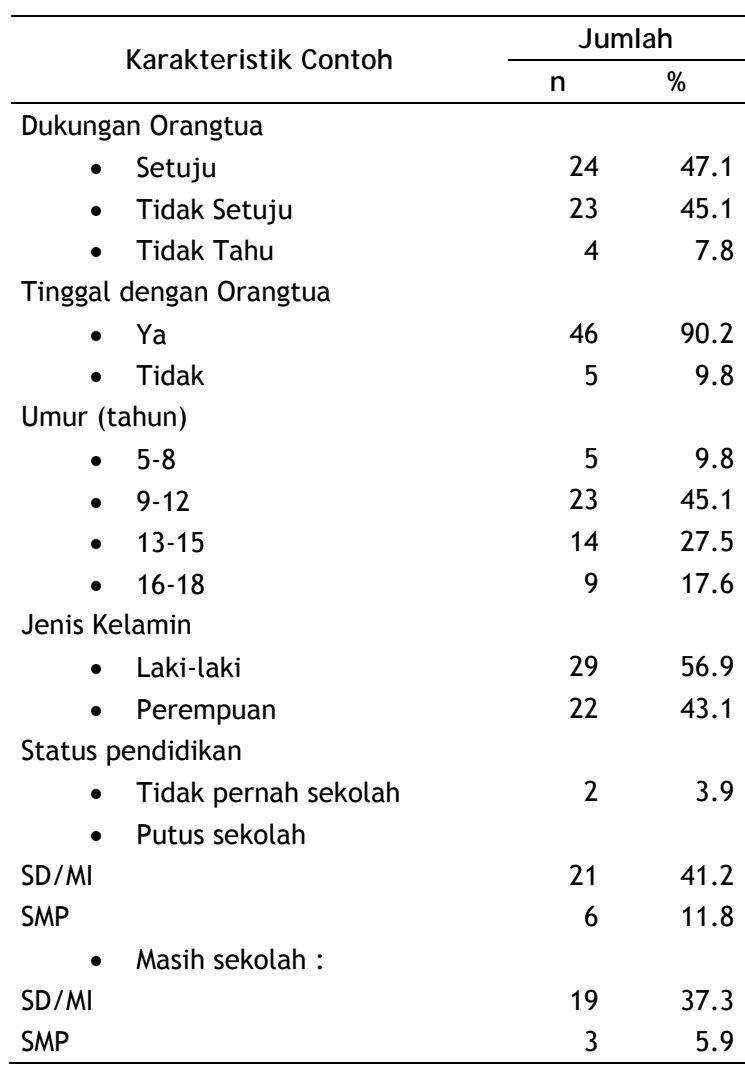

Tabel 1 menunjukkan bahwa 56.9\% contoh adalah laki-laki dan $43.1 \%$ adalah perem- puan. Jumlah contoh yang lebih banyak lakilaki diduga karena anak laki-laki memiliki kebebasan dan mampu berdapatasi dengan lingkungan jalanan sejak dini dibandingkan perempuan (Abdelgalil et al., 2004).

Umur contoh berada pada kisaran umur 5-18 tahun. Persentase umur terbesar berada pada kisaran umur 9-12 tahun (45.1\%) dan 1315 tahun (27.5\%). Persentase contoh yang putus sekolah lebih besar (52.9\%) dibandingkan contoh yang masih sekolah (43.2\%). Beberapa alasan contoh putus sekolah di antaranya tidak memiliki biaya, malu dan malas. Baik contoh yang masih sekolah (37.3\%) maupun putus sekolah (41.2\%) memiliki tingkat pendidikan SD/ MI. Contoh berhenti sekolah dan memilih untuk mencari uang di jalan disebabkan oleh ketidakmampuan ekonomi.

\section{Pola Aktivitas}

Pola aktivitas contoh meliputi frekuensi, lama dan jenis aktivitas yang dilakukan anak jalanan selama berada di jalan dalam waktu tertentu yang dilakukan secara terus-menerus. Contoh menghabiskan waktunya di jalan dengan berbagai macam aktivitas. Salah satu aktivitas yang dilakukan adalah bekerja agar contoh bisa memperoleh uang. Pekerjaan yang dilakukan contoh untuk memperoleh uang di antaranya adalah berjualan, mengamen, menyemir sepatu, mengelap mobil, menyewakan payung, meminta-minta dan sebagainya.

Jenis pekerjaan yang banyak dilakukan contoh adalah mengamen (72.5\%). Mengamen banyak dilakukan diduga karena jenis pekerjaan ini lebih cepat menghasilkan uang. Selain itu, sebesar $25.5 \%$ contoh melakukan lebih dari satu pekerjaan (ganda). Tabel 2 menunjukkan bahwa hampir separuh contoh bekerja 4-6 hari dalam seminggu (49\%). Contoh yang bekerja setiap hari sebesar $41.2 \%$ sedangkan contoh yang bekerja 1-3 hari sebesar 9.8\%. Rata-rata contoh turun ke jalan adalah 6 jam per hari. Sebagian besar contoh turun ke jalan selama 4-8 jam per hari (74.5\%).

Anak jalanan umumnya bekerja antara 4-18 jam per hari jika melakukan satu aktivitas atau sejumlah aktivitas dengan rata-rata 11 jam kerja per hari (UNICEF, 2001). Tabel 2 menunjukkan bahwa tidak ada contoh yang turun ke jalan untuk bekerja lebih dari 12 jam /hari. Hal ini diduga karena sebagian besar contoh termasuk kategori children on the street sehingga hanya turun ke jalan untuk mencari uang (pekerja anak) dan masih memiliki keluarga sehingga masih pulang ke rumah secara rutin. 
Pendapatan per hari yang diperoleh contoh beragam. Pendapatan terendah contoh ia lah Rp 5000 dan tertinggi adalah Rp 30000 serta rata-rata pendapatan contoh adalah $\mathrm{Rp}$ 14 451. Tabel 2 menunjukkan bahwa sebesar 56.9\% pendapatan contoh berkisar Rp 10000 Rp 20 000; 35.3\% contoh berpendapatan kurang dari Rp 10000 dan hanya 7.8\% contoh berpendapatan lebih dari Rp 20001.

Tabel 2. Sebaran Contoh berdasarkan Pola Aktivitas

\begin{tabular}{crr}
\hline \multicolumn{1}{c}{ Pola Aktivitas } & $\mathbf{n}$ & \multicolumn{1}{c}{$\%$} \\
\hline Jenis pekerjaan & & \\
- Berjualan & 1 & 2 \\
- Mengamen & 37 & 72.5 \\
- Ganda & 13 & 25.5 \\
Durasi (jam/hari) & & \\
- 4-8 & 38 & 74.5 \\
- 9-12 & 13 & 25.5 \\
- >12 & 0 & 0 \\
Jumlah Hari Kerja & & \\
- 1-3 & 5 & 9.8 \\
- 4-6 & 25 & 49 \\
- 7 & 21 & 41.2 \\
Pendapatan (per hari) & & \\
- $\quad$ Rp 10 000 & 18 & 35.3 \\
- Rp10 001-20 000 & 29 & 56.9 \\
- Rp20.001 & 4 & 7.8 \\
\hline
\end{tabular}

Pendapatan yang diperoleh contoh selama turun ke jalan digunakan untuk berbagai macam kebutuhan. Sebesar 68.6\% contoh membagi pendapatannya untuk orang tua dan diri sendiri. Contoh memberikan sebagian atau seluruh pendapatannya kepada orang tua karena contoh ingin membantu orang tua. Hal ini sesuai dengan alasan utama contoh turun ke jalan yaitu karena faktor ekonomi.

Tabel 3. Sebaran Alokasi Pendapatan Contoh

\begin{tabular}{lrr}
\hline \multicolumn{1}{c}{ Alokasi Pendapatan } & $\mathbf{n}$ & \multicolumn{1}{l}{$\%$} \\
\hline Untuk orangtua & 10 & 19.6 \\
Untuk diri sendiri & 6 & 11.8 \\
Untuk orangtua dan diri sendiri & 35 & 68.6 \\
Total & 51 & 100 \\
\hline
\end{tabular}

Alokasi pendapatan contoh untuk diri sendiri digunakan untuk berbagai macam kebutuhan. Kebanyakan contoh menggunakan pendapatannya untuk jajan atau makan daripada menabung. Sebagian besar contoh tidak mengalokasikan pendapatannya untuk ongkos transportasi. Hal ini diduga karena jarak rumah contoh menuju jalanan cukup dekat sehingga bisa ditempuh dengan berjalan kaki.

\section{Kebiasaan Makan \\ Frekuensi Pangan}

Beras merupakan pangan sumber karbohidrat yang sering dikonsumsi contoh. Ratarata konsumsi beras contoh adalah 2 kali/hari. Pangan sumber karbohidrat yang dikonsumsi dengan frekuensi tidak terlalu sering adalah jagung (5.7 kali/bulan), ubi jalar (5.2 kali/ bulan), singkong (5.1 kali/bulan). Mie merupakan pangan yang jarang dikonsumsi yaitu 3.1 kali/bulan. Semua pangan sumber karbohidrat diperoleh dengan cara membeli.

Sumber protein hewani yang paling sering dikonsumsi contoh adalah telur, ikan asin, susu, ikan pindang, dan daging ayam. Pangan sumber protein hewani yang tidak terlalu sering dikonsumsi adalah ikan tawar dan ikan laut yaitu 3.7 dan 2 kali/bulan. Pangan sumber hewani lain yaitu daging sapi dan kambing jarang dikonsumsi contoh. Hampir semua pangan sumber protein hewani diperoleh dengan membeli kecuali daging sapi dan kambing.

Pangan sumber protein nabati yang paling sering dikonsumsi contoh adalah tahu dan tempe. Kacang tanah, buncis, dan kacang merah tidak terlalu sering dikonsumsi contoh. Pangan yang jarang dikonsumsi adalah oncom, jengkol dan petai. Makanan-makanan ini dikonsumsi antara 1-3 kali/bulan. Semua pangan sumber protein nabati diperoleh contoh dengan membeli.

Sayuran yang paling sering dikonsumsi adalah tomat dan kangkung. Sayuran yang tidak terlalu sering dikonsumsi adalah bayam, wortel, kol, daun singkong, kacang panjang, mentimun dan nangka muda. Semua sayuran yang dikonsumsi diperoleh dengan membeli.

Buah yang sering dikonsumsi diantaranya jambu, pepaya, mangga, nanas, pisang, nangka tua, rambutan, dan jeruk. Namun buah yang paling sering dikonsumsi adalah rambutan (16,6 kali/bulan) dan jambu (13,7 kali/ bulan).

Hampir semua makanan jajanan dikonsumsi dengan frekuensi sering dalam sebulan. Namun, makanan jajanan yang paling sering dikonsumsi adalah gorengan yaitu tahu goreng (21.2 kali/bulan), pisang goreng (19.9 kali/ bulan) dan tempe goreng (19 kali/bulan). Makanan jajanan lainnya (batagor, minuman serbuk dan roti) dikonsumsi dengan frekuensi tidak terlalu sering (1.3 kali/bulan). Semua makanan jajanan yang dikonsumsi contoh diperoleh dengan membeli.

Pangan lainnya yang dikonsumsi contoh adalah gula, teh, kopi, saos, kerupuk, dan ke- 
cap. Semua pangan lainnya sering dikonsumsi dalam sebulan. Pangan lainnya yang paling sering dikonsumsi adalah gula (18.6 kali/bulan), teh (13,6 kali/bulan) dan kerupuk (12.8 kali/bulan) sedangkan yang tidak terlalu sering dikonsumsi adalah saos dan kecap. Kopi jarang dikonsumsi contoh dengan frekuensi $70.5 \mathrm{kali} /$ bulan. Semua pangan lainnya diperoleh contoh dengan membeli.

\section{Konsumsi Pangan}

Konsumsi pangan merupakan informasi tentang jenis dan jumlah pangan yang dimakan (dikonsumsi) seseorang atau kelompok orang pada waktu tertentu. Definisi ini menunjukkan bahwa konsumsi pangan dapat ditinjau dari aspek jenis pangan yang dikonsumsi dan jumlah pangan yang dikonsumsi. Dalam menghitung jumlah zat gizi yang dikonsumsi, kedua informasi ini (jenis dan jumlah pangan) merupakan hal yang penting. Batasan ini menunjukkan bahwa konsumsi pangan dapat ditinjau berdasarkan aspek jenis pangan dan jumlah pangan yang dikonsumsi (Kusharto \& Sa'adiyah, 2006).

Jenis pangan yang dikonsumsi contoh terbilang cukup beragam walaupun ada yang dikonsumsi dalam jumlah sedikit. Tabel 4 menunjukkan bahwa kontribusi energi (50.1\%), protein $(24.9 \%)$ dan Fe (31.7\%) terbesar berasal dari golongan serealia, umbi, hasil olahannya yaitu beras. Selain itu rata-rata konsumsi beras paling besar dibandingkan pangan yang lain. Rata-rata konsumsi protein hewani terbesar adalah telur sedangkan rata-rata konsumsi protein nabati terbesar adalah tahu. Sayuran yang paling banyak dikonsumsi adalah bayam sedangkan buah-buahan yang banyak dikonsumsi adalah rambutan. Rata-rata konsumsi vitamin A terbesar berasal dari sayuran yaitu 42.1\%. Sumber vitamin A terbesar berasal dari sayur sawi. Rata-rata konsumsi vitamin C terbesar adalah minuman(48.8\%) yang berasal dari minuman rasa buah.

\section{Tingkat Kecukupan Gizi}

\section{Tingkat Kecukupan Energi (TKE) dan Tingkat Kecukupan Protein (TKP)}

Kebutuhan tubuh akan zat gizi ditentukan oleh banyak faktor, antara lain tingkat metabolisme basal, tingkat pertumbuhan, aktivitas fisik dan faktor lainnya yang bersifat relatif (Supariasa et al., 2001).

Rata-rata konsumsi energi contoh adalah $1646 \mathrm{Kal}$ sedangkan kecukupan energi contoh adalah 1871 Kal. Jika rata-rata konsumsi dibandingkan dengan rata-rata kecukupan maka diperoleh rata-rata Tingkat Kecukupan Gizi (TKG). Rata-rata tingkat kecukupan energi contoh adalah $88 \%$ dan termasuk dalam kategori defisit tingkat ringan. Rata-rata konsumsi protein contoh adalah 38.7 gram sedangkan AKG contoh 46.3 gram. Rata-rata tingkat kecukupan protein contoh adalah 84\% dan termasuk ke dalam kategori defisit tingkat ringan.

Sebesar 37.3\% tingkat kecukupan energi contoh termasuk dalam kategori defisit tingkat berat. Persentase contoh yang termasuk dalam kategori normal sebesar $9.6 \%$ dan yang termasuk dalam kategori lebih sebesar $23.5 \%$. Berdasarkan Tingkat Kecukupan Protein (TKP), hampir separuh contoh (45.1\%) termasuk dalam kategori defisit tingkat berat. Persentase contoh yang termasuk dalam kategori normal sebesar $17.6 \%$ dan yang termasuk dalam kategori lebih sebesar $21.6 \%$.

Contoh yang mengalami tingkat kecukupan energi defisit tingkat berat disebabkan frekuensi makan yang jarang. Menurut Sukandar (2007) frekuensi makan mempengaruhi jumlah asupan makanan bagi individu dimana hal tersebut akan berpengaruh terhadap tingkat kecukupan gizi. Tingkat kecukupan protein contoh yang termasuk dalam kategori defisit tingkat berat disebabkan pangan sumber protein yang dikonsumsi contoh rendah walaupun mutu proteinnya baik.

Tabel 4. Rata-Rata Konsumsi Pangan, Energi Dan Zat Gizi Contoh

\begin{tabular}{|c|c|c|c|c|c|c|c|c|c|c|c|}
\hline Pangan & $\begin{array}{c}\text { Berat } \\
\text { (g/kap/hr) }\end{array}$ & $\begin{array}{c}E \\
(\text { Kal) }\end{array}$ & $\%$ & $\begin{array}{l}P \\
(g)\end{array}$ & $\%$ & $\begin{array}{c}\text { Fe } \\
(\mathrm{mg})\end{array}$ & $\%$ & $\begin{array}{l}\text { Vit A } \\
(\mathrm{mg})\end{array}$ & $\%$ & $\begin{array}{l}\text { Vit C } \\
\text { (mg) }\end{array}$ & $\%$ \\
\hline Serealia, umbi dan hasil olahannya & 461.2 & 962 & 58.4 & 14.4 & 37.0 & 3.8 & 31.7 & 4.1 & 0.9 & 1.5 & 3.4 \\
\hline Daging, telur, ikan dan hasil olahannya & 55.8 & 137 & 8.3 & 9.4 & 24.2 & 1.3 & 11.1 & 79.9 & 16.7 & 0.3 & 0.7 \\
\hline Kacang-kacangan dan hasil olahnnya & 73.8 & 156 & 9.5 & 9.1 & 23.4 & 3.3 & 27.5 & 0.1 & 0 & 0.3 & 0.8 \\
\hline Sayuran & 37.3 & 12 & 0.8 & 0.7 & 1.7 & 0.6 & 4.8 & 201.8 & 42.1 & 12.8 & 28.0 \\
\hline Buah & 44.4 & 15 & 0.9 & 0.2 & 0.5 & 0.2 & 1.4 & 66.1 & 13.8 & 7.9 & 17.3 \\
\hline Jajanan & 83.1 & 213 & 13.0 & 4.0 & 10.3 & 2.4 & 20.3 & 2.6 & 0.5 & 0.5 & 1.0 \\
\hline Serba-Serbi & 16.4 & 44 & 2.6 & 0.9 & 2.4 & 0.4 & 3.2 & 125.1 & 26.1 & 0.0 & 0.0 \\
\hline Minuman & 79.8 & 107 & 6.5 & 0.2 & 0.5 & 0.0 & 0.0 & 0.0 & 0.0 & 22.3 & 48.8 \\
\hline Total & 851.6 & 1646 & 100 & 38.9 & 100 & 12.1 & 100 & 479.6 & 100 & 45.7 & 100 \\
\hline
\end{tabular}




\section{Tingkat Kecukupan Vitamin dan Mineral}

Rata-rata konsumsi Fe, vitamin A dan vitamin C contoh adalah $12 \mathrm{mg}, 492.2 \mathrm{RE}$ dan $45.6 \mathrm{mg}$. Angka kecukupan $\mathrm{Fe}$, vitamin A dan vitamin C contoh adalah $16.7 \mathrm{mg}, 577.5 \mathrm{RE}$ dan $61.3 \mathrm{mg}$. Rata-rata tingkat kecukupan Fe dan vitamin C contoh termasuk dalam kategori kurang sedangkan rata-rata tingkat kecukupan vitamin A contoh termasuk kategori cukup.

Lebih dari separuh contoh (70.6\%) memiliki tingkat kecukupan Fe kurang. Hal ini karena konsumsi protein hewani contoh rendah dan sumber pangan Fe contoh terbesar berasal dari serealia. Menurut Almatsier (2006) sumber baik besi adalah makanan hewani, seperti daging, ayam, dan ikan. Sumber lainnya adalah telur, serealia tumbuk, kacang-kacangan, sayuran hijau dan beberapa jenis buah. Pada umumnya besi di dalam daging, ayam dan ikan mempunyai ketersediaan biologi tinggi, besi di dalam serealia dan kacang-kacangan mempunyai ketersediaan biologi sedang.

Lebih dari separuh contoh memiliki tingkat kecukupan vitamin A dan C kurang. Menurut Almatsier (2006) vitamin A terdapat dalam pangan hewani sedangkan karoten terutama di dalam pangan nabati. Sumber karoten adalah sayuran berwarna hijau tua serta sayuran dan buah-buahan yang berwarna kuning jingga. Vitamin C umumnya hanya terdapat di dalam pangan nabati yaitu sayur dan buah terutama yang asam. Vitamin $C$ juga banyak terdapat di sayuran daun-daunan dan jenis kol.

\section{Higiene Personal}

Menurut Widyati dan Yuliarsih (2002) usaha yang dapat dilakukan untuk mencegah datangnya penyakit pada higiene personal (kesehatan peseorangan) diantaranya, mandi minimal dua kali sehari, menyikat gigi, pakaian yang bersih, olahraga, minuman yang direbus dan mencuci tangan sebelum memegang makanan. Higiene personal yang baik dapat membantu dalam pencegahan penyakit.

Lebih dari separuh contoh telah memiliki kebiasaan mandi minimal 2 kali sehari, selalu mandi menggunakan sabun, menggosok gigi minimal 2 kali sehari, selalu menggunakan pasta gigi dan sering menggunakan alas kaki setiap keluar rumah. Menurut Rositawaty (2007), untuk memelihara gigi, gigi harus disikat minimal 2 kali sehari secara teratur sehingga kebersihan mulut akan terjaga.

Hampir separuh contoh (62.7\%) jarang keramas sedangkan contoh yang memiliki kebi- asaan keramas hanya sebesar $37.3 \%$. Lebih dari separuh contoh $(56.9 \%)$ tidak pernah menggunakan handuk milik sendiri. Sebagian besar contoh selalu menjemur handuknya setelah digunakan. Sebesar $45.1 \%$ contoh jarang mencuci handuknya. Contoh mencuci handuknya jika benar-benar sudah kotor. Contoh yang sering mengganti baju 2 kali atau lebih dalam sehari sebesar $49.7 \%$. Mandi dan mengganti pakaian secara teratur penting untuk kebersihan dan penampilan seseorang yang baik. Hal ini juga termasuk higiene pencegahan terhadap penyakit seperti skabies, cacing gelang, trakoma, konjungtivitis dan tifus (WHO 2008).

Hampir separuh contoh (49.7\%) terbiasa mencuci tangan menggunakan air bersih dan hanya $14.4 \%$ contoh yang menggunakan sabun. Lebih dari separuh contoh (52.9\%) jarang menggunting kuku minimal seminggu sekali. Contoh menggunting kukunya bila merasa kukunya sudah kotor.

Tabel 5. Skor Penilaian Higiene Personal Contoh

\begin{tabular}{lcc}
\hline \multicolumn{1}{c}{ Klasifikasi } & $\mathbf{n}$ & $\%$ \\
\hline Rendah (11-16) & 4 & 7.8 \\
Sedang (17-21) & 20 & 39.2 \\
Tinggi (22-26) & 27 & 52.9 \\
Total & 51 & 100.0 \\
\hline
\end{tabular}

Sebesar $52.9 \%$ contoh memiliki skor higiene personal tinggi dan $39.2 \%$ contoh memiliki skor sedang. Hal ini menunjukkan bahwa sebagian besar contoh sudah menjaga kebersihan tubuh dan pakaian dalam kehidupan seharihari.

\section{Hubungan Pola Aktivitas dengan Konsumsi Pangan dan Tingkat Kecukupan Gizi}

Contoh menghabiskan waktunya di jalan dengan berbagai macam aktivitas. Salah satu aktivitas yang dilakukan adalah bekerja agar contoh bisa memperoleh uang. Pekerjaan yang dilakukan contoh untuk memperoleh uang diantaranya adalah berjualan, mengamen, menyemir sepatu, mengelap mobil, menyewakan payung, meminta-minta dan sebagainya. Hasil analisis korelasi Spearman menunjukkan bahwa tidak terdapat hubungan yang signifikan $(p>0,05)$ antara jenis pekerjaan yang dilakukan contoh dengan tingkat kecukupan gizi.

Durasi contoh turun ke jalan merupakan waktu yang dihabiskan contoh untuk beraktivitas di jalan dalam sehari. Sebagian besar contoh menghabiskan waktunya di jalan selama 4-8 jam dalam sehari. Waktu yang dihabiskan contoh untuk turun ke jalan dalam 
sehari diduga akan menyebabkan pola makan yang tidak teratur sehingga berpengaruh terhadap konsumsi pangan contoh. Namun hasil korelasi Pearson menunjukkan bahwa tidak terdapat hubungan yang signifikan $(p>0,05)$ antara durasi contoh berada di jalan dengan konsumsi dan tingkat kecukupan energi, protein, zat besi dan vitamin $C$ contoh.

Tidak adanya hubungan yang signifikan antara jenis pekerjaan dan durasi dengan tingkat kecukupan gizi contoh karena sebagian besar contoh menghabiskan waktu di jalan selama 4-8 jam sehingga contoh masih dapat membagi waktu antara bekerja dan makan. Berbeda halnya dengan konsumsi dan tingkat kecukupan vitamin A contoh. Hasil korelasi Pearson menunjukkan bahwa terdapat hubungan yang signifikan positif antara durasi contoh berada di jalan dengan konsumsi vitamin $A(p<0.05$, $r=0.286)$ dan tingkat kecukupan vitamin A contoh $(p<0.05, r=0.282)$ tetapi hubungannya sangat lemah.

\section{Hubungan Tingkat Kecukupan Energi dan Zat Gizi dengan Status Gizi}

Pengukuran status gizi contoh dilakukan dengan metode antropometri melalui perhitungan Indeks Massa Tubuh menurut umur (IMT/U). IMT/U digunakan untuk anak yang berumur 5-19 tahun dengan menggunakan persentil. Berdasarkan perhitungan IMT/U sebagian besar contoh memiliki status gizi normal (96.1\%) dan 3.9\% berstatus gizi kurus.

Tabel 6. Sebaran Contoh berdasarkan Status Gizi

\begin{tabular}{lcc}
\hline \multicolumn{1}{c}{ Klasifikasi } & $\mathbf{n}$ & $\%$ \\
\hline Kurus & 2 & 3.9 \\
Normal & 49 & 96.1 \\
\hline Total & 51 & 100.0 \\
\hline
\end{tabular}

Hasil analisis korelasi Spearman menunjukkan bahwa tidak terdapat hubungan yang signifikan tingkat kecukupan energi dan zat gizi ( $p>0.05)$ dengan status gizi contoh. Pada penelitian ini recall yang dilakukan adalah 1x24 jam sehingga diduga memberikan hasil yang kurang representatif. Menurut Supariasa et al. (2001) apabila recall hanya dilakukan 1x24 jam maka data yang diperoleh kurang representatif untuk menggambarkan kebiasaan makan individu. Kelemahan recall 1x24 jam adalah tidak dapat menggambarkan asupan makan sehari-hari sedangkan kelebihan dari recall 1x24 jam adalah mudah, murah, cepat serta tidak membebani responden.

\section{Hubungan Higiene Personal dengan Status Kesehatan}

Selain menghadapi masalah gizi, anak jalanan juga beresiko mengalami gangguan kesehatan. Menurut Sekartini et al. (2004) kelompok anak jalanan merupakan kelompok yang rentan terhadap masalah kesehatan. Gangguan kesehatan tersebut adalah penyakit Infeksi Saluran Pernapasan Atas (ISPA), diare dan penyakit kulit. Status kesehatan contoh diketahui melalui pemeriksaan fisik.

Tabel 7. Sebaran Contoh berdasarkan Status Kesehatan

\begin{tabular}{cccc}
\hline Penyakit & & $\mathbf{n}$ & $\%$ \\
\hline \multirow{2}{*}{ ISPA } & Ada & 19 & 37.3 \\
& Tidak & 32 & 62.7 \\
\hline \multirow{2}{*}{ Diare } & Ada & 12 & 23.5 \\
& Tidak & 39 & 76.5 \\
\hline \multirow{2}{*}{ Penyakit kulit } & Ada & 9 & 17.6 \\
& Tidak & 42 & 82.4 \\
\hline
\end{tabular}

Sebagian besar contoh memiliki status kesehatan yang baik. Hal ini ditunjukkan pada Tabel 7 bahwa lebih dari separuh contoh tidak memiliki gangguan penyakit ISPA $(62.7 \%)$, diare (76.5\%) dan penyakit kulit $(82.4 \%)$.

Tabel 8. Sebaran Contoh berdasarkan Status Kesehatan dan Higiene Personal

\begin{tabular}{|c|c|c|c|c|}
\hline \multirow{2}{*}{$\begin{array}{l}\text { Higiene } \\
\text { Personal }\end{array}$} & \multicolumn{4}{|c|}{ Status Kesehatan } \\
\hline & $\mathrm{n}$ & $\%$ & $\mathrm{n}$ & $\%$ \\
\hline & \multicolumn{2}{|c|}{ ISPA } & \multicolumn{2}{|c|}{ Normal } \\
\hline Rendah & 2 & 3.9 & 2 & 3.9 \\
\hline Sedang & 9 & 17.6 & 11 & 21.6 \\
\hline Tinggi & 8 & 15.7 & 19 & 37.3 \\
\hline \multirow[t]{3}{*}{ Total } & 19 & 37.3 & 32 & 62.7 \\
\hline & \multicolumn{4}{|c|}{$p>0.05$} \\
\hline & \multicolumn{2}{|c|}{ Diare } & \multicolumn{2}{|c|}{ Normal } \\
\hline Rendah & 1 & 2 & 3 & 5.9 \\
\hline Sedang & 4 & 7.8 & 16 & 31.4 \\
\hline Tinggi & 7 & 13.7 & 20 & 39.2 \\
\hline \multirow[t]{3}{*}{ Total } & 12 & 23.5 & 39 & 76.5 \\
\hline & \multicolumn{4}{|c|}{$p>0.05$} \\
\hline & \multicolumn{2}{|c|}{ Penyakit Kulit } & \multicolumn{2}{|c|}{ Normal } \\
\hline Rendah & 0 & 0 & 4 & 7.8 \\
\hline Sedang & 4 & 7.8 & 16 & 31.4 \\
\hline Tinggi & 5 & 9.8 & 22 & 43.1 \\
\hline \multirow[t]{2}{*}{ Total } & 9 & 17.6 & 42 & 82.4 \\
\hline & \multicolumn{4}{|c|}{$p>0.05$} \\
\hline
\end{tabular}

Apabila dilihat dari setiap komponen higiene personal, terdapat hubungan yang signifikan negatif $(p<0.05, r=-0.294)$ antara kebiasaan mencuci tangan menggunakan sabun dengan diare. Hal ini menunjukkan bahwa semakin sering mencuci tangan menggunakan sabun 
maka kejadian diare semakin rendah. Menurut Rositawaty (2007) hal termudah untuk menghindari penyakit diare dan muntaber adalah dengan mencuci tangan dengan sabun sebelum makan, setelah buang air besar dan kecil ataupun menyeka lendir ketika terserang flu.

Berdasarkan Tabel 8 contoh yang menderita ISPA sebagian besar memiliki higiene personal sedang (17.6\%). Contoh yang menderita diare dan penyakit kulit sebagian besar memiliki higiene personal tinggi $(13.7 \%$ dan $9.8 \%$ ). Hal ini menunjukkan bahwa higiene personal yang baik belum tentu diikuti dengan semakin baiknya kesehatan seseorang. Selain itu, hasil korelasi Spearman menunjukkan tidak terdapat hubungan yang signifikan ( $p>0.05)$ antara higiene personal contoh dengan status kesehatan contoh (ISPA, diare dan penyakit kulit). Keadaan demikian diduga lingkungan tempat tinggal contoh yang kurang sehat. Kondisi lingkungan rumah berpengaruh terhadap tingkat kesehatan masyarakat. Makin buruk kondisi lingkungan rumah maka status kesehatan penghuninya makin menurun (Entjang, 2000). Perilaku yang sehat tidak cukup bila tidak didukung oleh lingkungan yang sehat karena selain diperlukan perilaku hidup yang sehat diperlukan kondisi lingkungan yang baik.

\section{Hubungan Status Gizi dengan Status Kesehatan}

Salah satu masalah kesehatan yang terjadi pada anak jalanan adalah keadaan kurang gizi karena pola makan yang tidak teratur. Keadaan kurang gizi merupakan salah satu faktor penyebab mudahnya seseorang terkena penyakit infeksi, hal ini karena sistem kekebalan tubuh alami yang dimiliki orang melemah (Indriani, Adiningsih \& Mahmudiono 2006). Hasil analisis korelasi Spearman menunjukkan bahwa tidak terdapat hubungan yang signifikan $(p>0,05)$ antara tingkat kecukupan energi dan zat gizi dengan status kesehatan contoh. Hal ini disebabkan sebagian besar contoh memiliki status kesehatan yang normal yaitu tidak terdapat kejadian ISPA, diare dan penyakit kulit. Terdapat faktor lain yang berpengaruh terhadap kesehatan seperti kekebalan (daya tahan tubuh). Meskipun agen penyebab penyakit menyerang manusia jika memiliki daya tahan tubuh yang tinggi maka tidak akan sakit (Entjang, 2000).

Ada hubungan timbal balik antara penyakit infeksi dengan tingkat keadaan gizi. Tingkat keadaan gizi yang baik akan memberikan resistensi yang tinggi dari tubuh terhadap berbagai penyakit infeksi. Sebaliknya infeksi berbagai penyakit akan memperjelek tingkat keadaan gizi karena zat gizi yang didapat dari makanan tidak dapat dimanfaatkan oleh tubuh (Roedjito, 1989). Namun hasil analisis Spearman menunjukkan bahwa tidak terdapat hubungan yang signifikan ( $p>0,05)$ antara status gizi dengan status kesehatan contoh. Hal ini disebabkan sebagian besar contoh memiliki status gizi dan kesehatan yang normal.

\section{KESIMPULAN}

Sebagian besar anak jalanan adalah lakilaki, berusia antara 9-12 tahun, putus sekolah, dan berpendapatan rata-rata 14 451/hari, dan termasuk kategori children on the street. Sebesar $37.3 \%$ dan $45.1 \%$ anak jalanan berturutturut memiliki Tingkat Kecukupan Energi dan Tingkat Kecukupan Protein defisit tingkat berat. Lebih dari separuh anak jalanan memiliki Tingkat Kecukupan Fe, vitamin A, dan vitamin $C$ yang kurang.

Sebagian besar anak jalanan memiliki skor hygiene personal tinggi dan status gizi dan kesehatan normal. Terdapat hubungan yang signifikan antara kebiasaan mencuci tangan menggunakan sabun dengan kejadian diare.

\section{DAFTAR PUSTAKA}

Abdelgalil S et al. 2004. Household and Family Characteristic of Street Children in Aracaju, Brazil 89: 817-820. www. archdischild.com. [3 April 2009]

Almatsier S. 2006. Prinsip Dasar ilmu Gizi. Gramedia Pustaka Utama, Jakarta.

Entjang I. 2000. IImu Kesehatan Masyarakat cetakan ke 14. Alumni, Bandung.

Indriani D, S Adiningsih dan T Mahmudiono. 2006. Hubungan Life Style Anak Jalanan terhadap Kejadian Penyakit Paru : Studi Kasus di Yayasan Insani Surabaya. www. litbangdepkes.go.id. [Desember 2008]

Khomsan A. 2009. Garis Kemiskinan yang Baru. www.suarapembaruancom. [Juni 2009]

Kusharto CM dan NY Sa'adiyah. 2006. Diktat Penilaian Konsumsi Pangan. IPB Press, Bogor. 
Moeliono L. 2001. Anak Jalanan di Jakarta: Antara Kerentanan dan Ketahanan. Warta Demografi tahun 31 no 4: 21-26

Roedjito D. 1989. Kajian Penelitian Gizi. Mediyatama Sarana Perkasa, Jakarta.

Rositawaty S. 2007. 25 Kiat Sehat Bugar. PT Karya Kita, Bandung.

Sekartini et al. 2004. Masalah kesehatan anak jalanan di rumah singgah. Medika, 30(12), 774-777.

Soekirman. 2000. Ilmu Gizi dan Aplikasinya. Direktorat Jendral Pendidikan Tinggi. Departemen Pendidikan Nasional, Jakarta.

Sukandar D. 2007. Studi Sosial Ekonomi, Aspek Pangan, Gizi dan Sanitasi (Petani Sawah Beririgasi di Banjar Jawa Barat). Depar- temen Gizi Masyarakat. Fakultas Ekologi Manusia, IPB, Bogor.

Supariasa IDN, B Bakri, \& I Fajar. 2001. Penilaian Status Gizi. Buku Kedokteran EGC, Jakarta.

UNICEF. 2001. The Situation of Street Children in Cairo and Alexandria Including The Children's Drug Abuse and Health/ Nutritional Status 1-89. www.UNICEF. org. [4 januari 2009]

[WHO].World Health Organization. 2008. Healthy Villages : a Guide for Communities and Community Health Workers 65-72. www.WHO.org .[Desember 2008]

Widyati $\mathrm{R}$ dan Yuliarsih. 2002. Higiene dan Sanitasi Umum dan Perhotelan. Gramedia Widiasarana Indonesia, Jakarta. 